boundary-making-for, after all, there are no frontiers in Europe which can in these days of modern warfare be considered as providing a sure defencebut in regard rather to the stability of the States concerned. A great experiment has been made in the new settlement of Europe, and an experiment which contains at least the germs of success. But in many ways it falls far short of perfection, and even if it were perfect it could not be permanent. The methods which ought to be adopted to render it more equable and to adapt it to changing needs it is not for us to discuss here. But as geographers engaged in the study of the ever-changing relations of man to his environment we can play an important part in the formation of that enlightened public opinion upon which alone a society of nations can be established.

\title{
Economics and Statistics at the British Association.
}

THE meetings of Section F (Economics and Statistics) at the recent meeting of the British Association at Cardiff were characterised by the greater part taken in the programme by the younger students of economics, and the result augurs well for the future of the science. What some of the readers of papers may have lacked in experience and authority they gained in freshness of outlook, in readiness to face the new facts of the post-war situation, and in refusal to be bound by the views of the older generation. It would have been interesting had some of the older representatives of the science been present to see the clash of the old ideas and the new; in their absence some of the less orthodox views went almost unchallenged.

In the first meeting of the Section the application of the co-operative method to economic life was urged in two connections. Mr. L. Smith Gordon (arguing from his experience of Irish conditions, in which he has been associated with Sir Horace Plunkett) dwelt on the necessity of treating agriculture as an industry to be organised on a scientific basis if its psychological and economic demands were to be reconciled with modern conditions. Such a scientific basis could only be found in co-operation. In his view, the undoubted advantages of large-scale farming lay not in the actual work of production, but in the handling and sale of the goods produced; and this thesis he maintained in an examination of the economies open to agriculture. But such advantages do not necessitate the existence of large farmers; the same results can be obtained through the adoption by small men of the co-operative methods already applied in Denmark, Belgium, and Germany, and this has the further advantage of building up a numerous race of independent, prosperous small farmers.

Mr. J. Lassen, a Dane, with twenty years' experience of England, argued for the introduction into this country of the Danish system of credit corporations, and supported his case by a detailed examination of the Danish method. The unique point of the system is that, whereas most financing is usually carried out through corporations of lenders (banks, trust companies, etc.), the Danish system begins with a corporation of borrowers. The borrowers, mainly belonging to one locality, and being known to each other, give joint security for loans, and the general public are asked to lend on this first-class mortgage security. That the system has worked well in Denmark was obvious from its history, but the writer was unable entirely to satisfy the sceptics on two points : first, how, if the system were introduced here, the hard-headed Englishman could be induced to accept unlimited liability; and, secondly, how the public could be induced to subscribe to bonds which are liable to depreciation and do not yield an abnormally high rate of interest. There seemed to be some subtle difference in the psychology' of the Dane and the Englishman which remained unexplained.

From co-operation the Section passed to the conNo. 2655 , VOL. IO6] sideration of coal. Mr. J. O. Cheetham analysed the present coal situation with special reference to its effects on the shipping interests of Cardiff. His main subject was the falling output, an examination of its causes and results, and suggestions for increasing production. In I9I 3 the coal produced in the United Kingdom amounted to $287,000,000$ tons, in I9I9 to $229,000,000$ tons-a fall of $58,000,000$ tons. In the same period the numbers employed in the industry increased from $1,128,000$ by 63,000 to $1,191,000$; and the output per person employed in the industry fell from 262 tons to 193 tons per annum. Thus an increase of 6 per cent. in the numbers employed synchronised with a decrease of 20 per cent. in total output. The writer also estimated (though from an ex parte statement by employers) that labour costs had increased from 63 per cent. of selling price in I9I4 to 75 per cent. of selling price in Igrg. Thus the period of Government control of the coal industry was also the period of the decline in total production and in production per head, and c, increase in relative labour costs of production. The special causes to which the decline in output was attributed were the introduction of the seven-hours' day and the failure of transport to convey the coal from the pit-head owing to the lack of trucks. In addition, the employers accused the miners of restricted production, and the employees in turn accused the owners of a deliberate holding-up of the development of mines. Mr. Cheetham seemed to hold both charges well grounded, but to think that what was a sin against the community on the part of the miners was natural and justifiable on the part of the owners-a distinction in which it was difficult to follow him. The president of the Section, Dr. Clapham, directed attention to the necessity of discovering to what extent the decreased output was attributable to the employment of a large amount of labour, not in getting coal, but in improving the state of the mines which had been inevitably neglected during the war period.

Mr. R. F. Adgie, in a paper entitled "The Conduct of the Mining Industry," distinguished between the economic and the psychological aspects of the problem of nationalisation. His thesis was that while from the purely economic point of view the argument for nationalisation was inconclusive, from the psychological viewpoint the balance of evidence pointed to the necessity of social ownership and control. On the economic side he pointed out that there had been an undefined amount of waste connected with the conduct of the industry under private ownership in the past. There was a good deal in distribution, since coal sold at the pit-head for $23^{s}$. $5 \mathrm{~d}$. was sold to the London consumer at $44 \mathrm{~s}$., the distribution charges thus amounting to 47 per cent. This leakage, however, could be stopped by large-scale or unified distribution. In some other directions the economic defects of the industry in recent years (reduced output, inefficient working, etc.) were exigencies of the war period, and were rapidly disappearing; and in others uncoordinated effort and inadequate capital resources had 
been at fault. But on the economic ground alone the analysis of the existing system had not revealed any advantages arising from social ownership and control which could not be achieved under capitalism. From the psychological point of view the case was different. While granting that the best organising ability might not be forthcoming in a socialised mining industry, he contended that in coal-mining the absence of the best trained direction was of less importance than in other industries. On the other hand, the technical staffs were willing to work under a socialised industry, and the miners would co-operate in no other. Without the technical staffs and the manual workers the industry could not function at all, and therefore, on the balance, the introduction of socialised ownership and control was, from the psychological aspect, inevitable.

The third sitting of the Section was devoted to financial problems. The address of Mr. A. H. Gibson covered a wide field, and was mainly historical in its treatment of its subject, "Credit: Inflation and Prices." After a survey of the development of credit institutions, Mr. Gibson pointed out that banks having by common consent collectively become custodians of the available purchasing power, this imposed on them the duty of not expanding credit at a rate proportionately greater than the increasing supplies of commodities, otherwise inflation would necessarily follow. In theory there was no limit to the expansion of bank credit, subject to the banks being able to obtain sufficient legal tender to meet current demands. He explained that "ways and means advances" by the Bank of England had had the effect of increasing the cash reserves of the banks during the war, and therefore banks were compelled to stop expansion of credit. $\mathrm{He}$ expressed the opinion that the banks would meet all the demands made on them for legitimate trade requirements. Traders would find that after a time the restriction of credit would enable them (by causing a fall in prices) to conduct their businesses on a lesser amount of floating capital than at present. He reviewed the necessary steps to be taken for deflation, the chief of which, he maintained, was the increase of production without a further increase in wages or profits. Other remedies were the reduction in the purchasing power of the community, the funding of the present floating debt by direct subscriptions from the public and not from the banks, and further retrenchment in public expenditure. The purchasing power of the community was now $x, 800,000,000 l$. greater than before the war, and $8_{5}$ per cent. of this represented bank credit expansion.

One of the worst evils of inflation was that it considerably reduced the export trade of the country because of higher costs of production. Under these conditions high prices would remain, for this country would have little to offer in exchange for imports of foodstuffs and raw materials from foreign countries. Thus the inflation, which appeared of little consequence to the Grovernment during the war, had all the seeds of disruptive forces within it in the case of a country situated like the United Kingdom, dependent for its existence on foreign trade. It had been a suicidal policy, and the harvest was yet to be reaped. High prices, discontent, labour troubles, and the probable loss in the future of a considerable part of our former volume of export trade were some of the fruits of this monetary inflation policy. The Government and the banks would make every effort to make the deflation as gradual as possible, but the process was bound to be accompanied by severe labour troubles and social discontent. He held, however, that however bitter the pill might be, it would be to the ultimate benefit of Labour to accept the inevitable reduction of wages and exert the maximum combined effort with Capital to increase production. A considerable increase in production might even allow the present level of wages to remain. Labour consumed probably 90 per cent. of the fruits of production, and had everything to gain by intensified output and everything to lose by wilfully diminished production.

At the last sitting of the Section the chief contribution was a paper by Mrs. Wooton on "The Future of Earning." Mrs. Wooton's thesis was that there is nothing inherently sacred in the notion of earning; that in recent times the payment of subsidies which had no relation to the value of work done had taken an increasing part in the remuneration of the worlser; and that the time had come to recognise the new ground of remuneration and to pay subsidies avowedly as such and not disguised as wages. As evidence of the tendency she pointed to the increased acceptance of the idea of a minimum wage and the growing favour of time- as distinguished from piece-wages. When the minimum wage paid exceeded the value of the work done for which it was paid, then it was no longer earned, but it was really a subsidy to the worker, and it was incompatible with the continuance of payment of a wage.

In the course of the last two or three vears research has been carried on by sub-committees of the Section into problems of credit and currency and into the place taken by women in industry during the war. Already several printed reports have been issued by these committees. The Committee on Women in Industry will probably issue a final report, and the Committee on Credit and Currency has been continued for another year and will issue its report in the summer of I $92 \mathrm{I}$.

\section{The International Congress of Physiologists.}

$A$ MONGST the results of the outbreak of war in A rgr4 was the making of it impossible for physiologists to assemble together as was their wont every three years. But now that Europe is recovering from the conflict, physiologists from different countries have been able to assemble, and they did so in Paris on July $\mathrm{I}^{-20}$.

The congress was under the presidency of Prof. Richet, of the chair of physiology at the Sorbonne, who was assisted by the vice-president, Prof. Gley, of the chair of general biology at the Collège de France. It was informally opened on the evening of Wednesday, July 14 , by a réunion amicalle in the laboratories of physiology at the Sorbonne. This conversazione gave opportunities for old friends to NO. 2655 , VOL. IO6] forgather and to make arrangements for the congressweek.

At ten o'clock on the following morning the congress was formally opened by a convocation in the great lecture-hall of chemistry at the Sorbonne. The amphitheatre had been transformed by means of crimson curtains and gilded chairs into a salle d'honneur for the occasion. Prof. Richet occupied the chair, and was supported by the Minister of Public Instruction, Prof. Gley, Prof. Fano, Prof. Fredericq of Liége, Profs. Sir E. Sharpey Schafer, Langley, Sherrington, Waller, and others.

The presidential address was simple, dignified, and impressive. The president began by recalling the names of those physiologists who had passed away 